\title{
THE INVISIBLE HAND FROM THE GRAVE
}

\author{
Barry Lam
}

$\rrbracket$

MAGINE WHAT A COUNTRY would be like if the dead could legally vote. We could pass a law permitting citizens to write a "perpetual vote" into their wills, allowing them to plan a vote for their preferred candidate type, party, or issue, in every election forever, and the government would see to it that these votes would compete with the votes of the living.

We have overwhelmingly good moral reasons to reject such a society. The dead, after all, are exempt from the benefits and harms of current political institutions. They are also perpetually underinformed. They cannot learn about the relevant facts that bear on sound political judgment, such as facts about technological, ecological, demographic, moral, and social changes. To give the dead perpetual political power would dilute the power of the living to shape the institutions that they and their descendants must live with. It could subject future generations to political institutions that operate completely contrary to their needs, values, and choices.

The political philosophers most influential to the founding of the United States recognized these moral considerations. Thomas Paine claimed that rule by the dead "is the most ridiculous and insolent of all tyrannies." Thomas Jefferson wrote in 1824, "Can one generation bind another, and all others, in succession forever? I think not. The Creator has made the earth for the living, not the dead. Rights and powers can only belong to persons, not to things, not to mere matter, unendowed with will."

If we agree with these sentiments that deny political power to the dead, do we have similarly good moral reasons to deny economic power to the dead? We certainly do not act like it. Trillions of dollars in the us economy and many legal institutions at all levels are tied up in executing the wishes of the dead in the United States and other common law countries like Britain, Ireland, and Australia. One simple example is the conditional bequest. You may require, as a condition of inheritance, that your grandchildren marry within a religious faith, that

1 Paine, Rights of Man, 11.

2 Jefferson to Major John Cartwright, June 5, 1824, 48. 
your wife smoke at least five cigarettes a day, or that a school be named after you in perpetuity, forbidding a change in name even if the school would otherwise go bankrupt. ${ }^{3}$ Conditional bequests have a long and entertaining history, and sometimes the conditions remain in effect many decades beyond the testator's death. ${ }^{4}$ The state enforces such conditional bequests on behalf of the dead even when the state has no independent interest in whether the conditions are satisfied, and all affected living parties prefer that the conditions not be upheld.

us law also recognizes a financial instrument called a dynasty trust, which allows individuals to secure wealth in a tax-sheltered trust for their descendants, in perpetuity if they choose. Such wealth can grow tax free, is transferred tax free, and can even be shielded from all future creditors. ${ }^{5}$ These dynasty trusts make it possible for heirs of the super-rich to sustain affluent lifestyles that are protected not only from the exhausting need to work, but also from the financial consequences of any poor decisions they might make. At the same time, these individuals do not have full property rights over the wealth in the trust. They could not, for instance, disinherit subsequent generations for any reason, as those rights are constrained by the wishes of the original dead founder of the trust. The irrevocable powers of the original dead founder include the amount distributed to each descendant, who counts as a descendant, what contingencies can lead to disinheritance, and how long the trust is to last. The compounding growth of the assets in such trusts can result in more and more wealth from future generations tied to the wishes of the dead.

A third legal instrument is the charitable trust, where the dead can earmark current and future wealth for some purpose considered "charitable." 6 This term is interpreted generously, and has been taken to include the care of abandoned guinea pigs and the preservation of Huey military aircraft, among other caus-

3 See In Re Estate of Feinberg, 919 N.E.2d 888 (Ill. 2009), and "Widow Fumes at Order to Start Smoking," San Antonio Express-News. In the case of Paul Smith College in New York, billionaire philanthropist Joan Weill offered a \$20 million donation to rescue the school from insolvency on the condition that the school be renamed "Paul Smith-Joan Weill College," contrary to the conditional bequest of Paul Smith, who, decades prior, bequeathed the land on which the college sits. The courts found in favor of the original bequest.

4 One of the most famous cases involves Wellington R. Burt, a nineteenth-century railroad industrialist, who famously and spitefully required the state to hold his wealth until twenty-one years after the death of his last grandchild who lived during his lifetime. It took ninety-one years for any of his descendants to inherit his wealth.

5 Sitkoff and Horowitz, "Unconstitutional Perpetual Trusts."

6 For a compelling recent discussion of the plutocratic tendencies of charitable foundations established by the currently living, see Reich, Just Giving. 
es. ${ }^{7}$ Charitable trusts, like dynasty trusts, can also earn money on behalf of their dead founders. That is, money earned from returns on trust assets such as capital gains or dividends are placed under the power of the wishes of the dead founder, as executed by trustees and courts. Like dynasty trusts, charitable trusts can also exist in perpetuity, so that trust assets are subject to the will of the dead founder forever. Nonprofit institutions like hospitals, museums, and universities can also have large amounts of their endowments constrained by the wishes of long-dead testators. With the wealth and power of a charitable trust, individuals in the past have decreed things like this: that a new park be built for the enjoyment of all and only white people, that a certain wing of a college dormitory be set aside for housing individuals of Confederate ancestry, and that there be an endowed professorship for the study of parapsychology. ${ }^{8}$

Many political institutions contribute to the enforcement of such dead-hand control. County district attorneys and state attorneys general have staff dedicated to enforcing charitable deeds, conditional bequests, and dynasty trusts. But most dead-hand control of wealth is subject to the rulings of courts. Large institutions, like Princeton University, Paul Smith's College, Newcomb College, Girard College, and the Hershey Company, to name a few, have faced major lawsuits over alleged violations of original donor intent. ${ }^{9}$ In almost all of these cases, with some exceptions, the job of the court is to determine what practice is most consistent with the wishes of the dead as stated in a particular deed or document, not whether the current state of the world is such that the money is better spent according to, rather than contrary to, the wishes of a dead donor.

It strikes me as odd that we are perfectly happy transferring economic power from the living to the dead via these three instruments - as though the reasons for preventing dead-hand control in politics do not carry over to personal wealth. Even more puzzling is that we prevent dead-hand control in other sectors of the economy. Founders or owners of businesses cannot stipulate legally binding business decisions to be carried out after their death. For instance, a founder cannot posthumously require that manufacturing be conducted in her hometown, or that the company will never do business in Japan. Such founders are perfectly within their rights to make such decisions while they are alive, but there are no

7 Cambridge Cavy Trust is one example of a guinea pig trust. The Huey aircraft example is from Madoff, Immortality and the Law.

8 See, for example, Evans v. Newton, 382 U.S. 296 (1966); Evans v. Abney, 396 U.S. 435 (1970); and Tennessee Div. of the United Daughters of the Confederacy v. Vanderbilt Univ., No. M2003-02632-COA-R3-CV (Tenn. Ct. App. May 3, 2005).

9 Girard College is the result of the most "litigated will in history." Interestingly, the Hershey case, also in Pennsylvania, does not trail far behind. 
legal institutions set up to execute a businessperson's wishes postmortem, and certainly no way for them to execute such wishes in perpetuity. As in the case of political rights, there is no particular mystery as to why. Markets and fashions change, sometimes drastically, and failing to change business practices out of some sense of loyalty or obligation to a past owner can lead very quickly to the death of the business. Requiring the state to enforce a founder's preferences can be tantamount to requiring the state to lead a business to its death.

It is a curious form of greed to feel entitled to eternal ownership of anything, and even more curious that the living permit and even promote it. To say the least, the idea that personal wealth may be tied to the wishes of the dead in perpetuity is in need of justification.

The philosophical literature on this topic is equivocal. Some philosophers believe that individuals can suffer posthumous harm, can be victims of posthumous moral wrongs, and are thereby afforded posthumous rights. ${ }^{10}$ These views, if they succeed, can be one way to underwrite the legitimacy of state enforcement of posthumous property rights.

On the other hand we have the considerations of Thomas Paine and Thomas Jefferson that fully generalize to economic power: the world belongs to the living. On this view, death is the final and ultimate alienation of all rights, including rights to personal property. As suggested by the cases of politics and private business, ideas about what it is good to do with power and resources ought to change with the changing conditions of the world. When it is in no living person's best interest for a sliver of the economy to be dedicated to the study of parapsychology, there should be no legal mechanism compelling expenditure on an endowed chair in this field. In general, the fact that a dead person willed that some pot of money be spent in a certain way is never a sufficient justification that the money be spent in that way.

These considerations are far from theoretical. As wealth inequality increases, and as returns on investment far outpace productivity growth, the wealthy are earmarking ever-larger amounts of money from the future economy to carry out their current wishes. ${ }^{11}$ The result could be a future economy that reflects the preferences of a past aristocracy rather than the majority of those living. Philosophers, even libertarians, have long worried about the threat that wealth inequality poses to justice when it can be perpetually inherited rather than earned. ${ }^{12}$ Inheritance is certainly a concern. But there is a more general concern I have that

10 Feinberg, The Moral Limits of the Criminal Law; Pitcher, "The Misfortunes of the Dead"; Levenbook, "Harming Someone after His Death"; Luper, "Posthumous Harm."

Masterfully documented by Picketty, Capital in the Twenty-First Century. 
reaches beyond the mere persistence of wealth inequality through inheritance. The concern is that there is a deep injustice inherent in disenfranchising the living by redistributing control over wealth to the dead, leading to the tyranny of the past opulent over the majority.

Ultimately, I contend that there is no justification for posthumous rights. The extent to which we feel that we owe anything to the dead can be explained completely in terms of the best interests of the living; to the extent that the wishes of the dead depart from the wishes of the living, there is overriding reason to reject any felt need to honor them. I believe that all of the reasons we have to reject the institutional handover of power from the living to the dead in politics and private business carry over to all power in all areas. The legal institutions we have erected to carry out the wishes of the dead currently in the common law countries are therefore unjust and must be reformed.

\section{FREEDOM OF TESTATION AND PERPETUAL CONTROL}

To understand how we have arrived at our current legal practices of wealth transfer, we need to grasp two crucial concepts. The first is freedom of testation and the second is perpetual control. Freedom of testation is the idea that your right to property includes the right to determine what happens to that property after your death. Perpetual control is the idea that the right to determine what happens to your property after death extends forever into the future. I argue that neither perpetual control nor freedom of testation are defensible as principles on which to base a legal framework for the disposition of private property after death.

\subsection{A Brief History of Perpetual Control and Its Problems}

If you have any interest in English literature, you will be familiar with the following plotline. A protagonist, be it a smart young woman or able young man, is unable to secure part of their father's estate due to some antiquated inheritance line established decades or centuries ago. Instead, some evil, sociopathic, or undeserving relative is the inheritor, requiring our protagonist to journey through life using only their entrepreneurial spirit or personal charms to secure their own living, resulting in a tale of the triumph of rugged individualism, or the tragedies of class stratification. This generic plot has as its setting a world in which the living are burdened by something called a fee tail (or entailed estate). The fee tail was an instrument by which a wealthy landowning individual could, through deed or custom, set up a perpetual, state-enforced inheritance line for an estate. On the one hand, subsequent inheritors were legally entitled to the estate as long as 
they were stipulated to be in the line of succession in the deed, regardless of what an inheritor from a previous generation had done with the estate. On the other hand, no subsequent inheritor had full property rights to the estate. They could not, for instance, decide to divide it evenly between disinherited siblings or revise the line of succession. No matter what subsequent inheritors wanted or needed, the original landowning individual's wishes would continue to be executed in subsequent generations.

Initially, fee tails traced back to feudal traditions rather that an act of will by an individual landowner. The fee tail was one of the last remnants of feudalism in Europe, with lines of succession more or less determined by customs and history, and almost always along patriarchal lines. Then, in 1540, Britain passed the Statute of Wills, giving individuals a degree of freedom of testation. ${ }^{13}$ This statute enabled landowners to draft fee tails by decision. Lines of succession would be chosen and codified into law from wills.

The Statute of Wills and the fee tail were in fact strange bedfellows. The statute represented a move away from feudalism and toward a market economy in Britain, where more robust individual property rights and the liberalization of real estate markets were the primary concerns of newer members of the landed gentry. If a piece of land was held in a fee tail, it was not marketable to purchasers. Such property was either completely unalienable (i.e., not saleable at all and available for ownership only by those in the line of succession), or saleable but subject to state intervention (that is, seizure-the state would need to "return" a purchased piece of land to a member of the line upon the death of a previous inheritor). Another way of seeing it is that land could not be easily converted to cash. Newer landed gentry wanted access to entailed land, and they wanted full rights of ownership over the land they acquired, but fee tails prevented such rights. The fee tail was in many ways completely contrary to the capitalist ethos emerging in Britain at the time.

On the other hand, once new landowners had acquired land, and had full rights of testation over the land, new landowners often wanted to become feudal landowners in their own right, keeping land within the family in perpetuity. What they found objectionable in fee tails as buyers they found perfectly attractive as owners. The Statute of Wills simultaneously expressed the right of landowners to control their property after their deaths, contrary to strict feudal inheritance traditions, and allowed new landowners to control their property completely in accordance with those feudal traditions if they chose.

Against this backdrop, the Rule against Perpetuities arose in the late seven-

13 According to the statute, two-thirds of one's estate could be freely testated. Baker, The $O x$ ford History of the Laws of England. 
teenth century, allowing fee tails in principle but curtailing them from extending too far into the future. In a famous case involving the Duke of Norfolk, a tribunal of judges executed a rule placing a time constraint on an individual's right to property after his death, a precedent that has survived over three hundred years. ${ }^{14}$ In the common law, the eventual formulation of "lives in being + 21 years" was the limit to the length of state enforcement of the wishes of the dead in fee tails. Very roughly, this means that the state will enforce the wishes of the dead for no longer than the length of the lives of the youngest people affected by the deed or trust, plus twenty-one years, which for practical purposes is about one hundred years.

By the time authors such as Jane Austen and George Eliot wrote some of our favorite English novels against the backdrop of the entailed estate, fee tails were mostly subject to the Rule against Perpetuities. Nonetheless, as such novels illustrate, the social harms of such instruments persisted from the times of feudalism. Some of the damaging effects of fee tails and feudalistic control of land include, but are not limited to, the perpetuation of class and gender inequality, the removal of wealth from free market competition, the protection of individuals from a certain form of liability (individuals could not be alienated from an important asset), family feuding, and the concentration of political power within families across generations. For good reason, fee tails were eventually outlawed for real estate. In theory, what remained of attempts to control other forms of wealth from the grave were subject to the Rule against Perpetuities. Beginning in the sixteenth century, the state-enforced power of the dead hand extended only as far as a couple of generations with respect to real estate-and this was, at least in principle, true for all other assets.

Then, in the second half of the twentieth century, common law countries and jurisdictions began a slow process of repealing the Rule against Perpetuities. ${ }^{15}$ In the United States, the relevant date is 1995, when the state of Delaware repealed the Rule against Perpetuities for all assets other than real estate. Delaware was followed by Alaska in 1997, and this set off an arms race for states and financial institutions to repeal their own versions of the rule. The motivation for states was to attract high-net-worth individuals to the state's trust and banking systems. The primary motivation for wealthy individuals was that trust agencies had begun devising a new kind of trust to help people avoid taxes on wealth at death, and to avoid such taxes in perpetuity for all subsequent successors. ${ }^{16}$ 
These repeals gave rise to the dynasty trust as we currently know it, which is in all respects the contemporary capitalist version of the fee tail. ${ }^{17}$

Dynasty trusts do not protect real estate, but they grant to the dead an equivalent-possibly a greater-power than the feudal fee tail. Assets that can be placed into dynasty trusts include things like stocks, bonds, shares in a hedge fund, and life insurance: assets that are easily convertible to cash, subject to compounding over generations, and, in the case of life insurance, can increase a trust's value tenfold upon the death of the testator. ${ }^{18}$ Not only are beneficiaries shielded from creditors as in a fee tail, they can also be protected by the dead hand from divorcee entitlements and obligations. Trust assets can be structured in such a way that they are in fact owned by the dead owner rather than subsequent generations, and so if a beneficiary crashes her car into a city building, the city cannot go after trust assets in a lawsuit, as they are not owned by the beneficiary. ${ }^{19}$ The testator can also place arbitrary conditions on whether and when beneficiaries can receive money. For instance, they can require that only heirs who enter into certain occupations will receive benefits, or that heirs who demonstrate unwanted behaviors like taking drugs, smoking, or converting to Catholicism, will not. ${ }^{20}$ The dead can decide how much or how little power subsequent generations have to control parts of the trust. ${ }^{21}$ In effect, a dynasty trust is like a complicated conditional bequest-except that a dynasty trust allows the dead testator to earn unlimited amounts of money after death, and to conditionally bequeath such earnings for each subsequent generation, not just the one that follows after her own death.

In many ways, the dynasty trust has the potential to be at least as harmful as the medieval fee tail. The perpetuation of wealth and class inequality is a consequence of both. The dynasty trust, like the fee tail, creates a class of citizens who do not pay the same taxes as others do, who are not financially liable for wrongdoing as others are, and are therefore afforded state privileges and protections others are not. They are afforded such things at birth simply in virtue of the fact that a wealthy dead ancestor wished that this be so. On the other hand, beneficiaries are subject to coercive pressures if the trust requires antiquated or arcane conditions on obtaining benefits. True, the lucky descendants are free

Sitkoff and Schanzenbach, "Jurisdictional Competition of Trust Funds."

To see how this works, roughly, imagine that you purchase a life insurance policy that pays out $\$ 10$ million upon your death. Such a policy might be worth $\$ 1$ million now, and it can be placed in the trust to pay future beneficiaries.

Madoff, Immortality and the Law. 
to refuse such benefits, but it is undeniably manipulative and maybe cruel to be confronted with the choice between a million dollars and the love of your life who happens to worship the wrong God. The dead are creating conditions that artificially incentivize their descendants to want to shape themselves according to the dead's wishes.

Finally, for those who care about capitalism and markets, dynasty trusts alienate large amounts of capital from the free market, subjecting it to the preferences and choices of someone who died long ago rather than those of individuals currently competing in the marketplace. It is no surprise that Adam Smith characterizes the dynasties of his day, entailed estates, as "barbarous" and "absurd" in The Wealth of Nations. ${ }^{22}$ A dynasty trust is a way to hoard capital, i.e., to take from the fruits of investment and hold it forever for disbursement to a small class of people at a comparatively miserly rate. Economic growth slows or shrinks when the living hoard rather than spend capital. ${ }^{23}$ When the dead hoard money, we cannot justify it by saying that it is the free exercise of rational agents participating in the market. We must remember that the dead are not around to carry out their wishes. It is the state and court system that enforce the wishes of the dead. When the dead are allowed to hoard capital, what you have is the state intervening in the economy to actualize the preferences of dead people to hoard or spend, rather than the rational choices of living actors. There is no market-oriented justification for this practice. ${ }^{24}$

We can generalize the argument by taking things to the limiting case. If the perpetual control of wealth is legitimate, then it is legitimate for an individual to perpetually refuse to alienate their wealth upon their own death. If earnings on assets rightfully belong to the dead, and must be spent or held according to their wishes, then given a sufficiently greedy set of high-worth people, there is a possible world in which it is legitimate for no property to be under the control

22 "But in the present state of Europe, when small as well as great estates derive their security from the laws of their country, nothing can be more completely absurd. They are founded upon the most absurd of all suppositions, the supposition that every successive generation of men have not an equal right to the earth, and to all that it possesses; but that the property of the present generation should be restrained and regulated according to the fancy of those who died perhaps five hundred years ago" (Smith, The Wealth of Nations, 384).

23 Keynes. The General Theory of Employment, Interest and Money; Rowe, "Keynesian Parables of Thrift and Hoarding."

24 Haslett, "Is Inheritance Justified?" argues that asymmetric transfers like posthumous gifting violate equality of opportunity constraints of market capitalism, and are illegitimate as a result. Reich (Just Giving) argues that foundational, philanthropic giving, whether during life or death, is anti-market because such giving is unaccountable to consumer demand and shareholders, sells no goods, and has no marketplace competitors. 
of anyone living. These Maximal Scrooges would be fully within their rights to ensure that the state enforce their wishes not to alienate any of their property to anyone. The only role for living people would be to protect the wealth of the dead from other living people. If this world is absurdly unjust, then it is unjust for the very reason that the principle of perpetual control is unjust.

I am not going to proceed any further in arguing that perpetual control is a bad thing. In this day and age, how much time do we need to make a case against feudal practices, whether on grounds of economic justice or libertarian free market principles? The fee tail was always unjust, and was never considered an instrument consistent with capitalism. But for some reason, the dynasty trust is. To the extent that it is, it is because of a principle of property rights that seems to be built into contemporary conceptions of property rights: freedom of testation.

\subsection{Freedom of Testation}

Philosophical justifications for free testation in the modern period date to Hugo Grotius, and can be found subsequently in the English tradition in John Locke and John Stuart Mill. ${ }^{25}$ The justification takes for granted the modern conception of property rights. Whatever it means to legitimately acquire and own property, giving it away is one legitimate way to transfer such rights. Freedom of testation then likens testation to the power of gifting. ${ }^{26}$ If I have a right to give away $X$, then I am free to give away $X$ on some condition. One condition is a deferment. I can give my property away later, and after my death is certainly later. In addition, any potential recipient of a gift is free to refuse, and thus the offering of a gift, on whatever conditions, imposes no loss on a recipient. Since a gift can be deferred according to the wishes of the owner, a bequest after death is simply a deferred gift, and a conditional bequest simply an instance of a conditional gift. A dynasty trust or charitable trust, then, is simply a deferred conditional bequest with future generations or charitable purposes as the target recipient and the arbitrary stipulations in a deed are the conditions. Almost all of the practices I have out-

For an extensive discussion of the classical liberal responses to feudalism and inheritance of property rights, see Halliday, Inheritance of Wealth, ch. 2.

Grotius writes, "Aside from all positive law, intestate succession, as it is called, after ownership has been established, has its origin in natural inference as to the wishes of the deceased. Since the force of ownership was such that it could be transferred to another at the will of the owner, so also in case of retention of ownership at the time of death.... If any one had given no indication of his wishes, nevertheless, since it was not credible that his intention was to yield his property after his death to the first who would take it over, the inference is that his property is to belong to the person to whom it is especially probable that the dead man had wished that it should belong" (The Rights of War and Peace, including the Law of Nature and of Nations, 1625). 
lined that honor the wishes of the dead in personal wealth can be derived from freedom of testation.

But the argument from freedom of gifting to freedom of testation presupposes that death does not alienate an owner from her rights to property. Get rid of this assumption, and freedom of testation cannot be derived. On the competing view that death alienates me from my property rights, I could no more give you my property after I die than I could give it to you after I have sold it to someone else, since selling is a way of alienating my rights. In life, we recognize selling, gifting, and some forms of confiscation (for civil liabilities, for instance) as legitimate alienations of property rights. We do not recognize death. But should we?

I do not think that it is an intuitive or basic assumption that death fails to alienate property rights. Most cultures and countries do not see freedom of testation as a natural or universal right. Primogeniture, for instance, has a much longer history as a practice in many cultures than free testation. In places and times where primogeniture has not held sway, inheritance practices seem to vary greatly depending on the social organization of a culture, whether it is misogynistic, agrarian, pastoral, colonial, and so forth. ${ }^{27}$ In fact, Max Weber observed in the late nineteenth century that "complete, or nearly complete, liberty of testation is only recorded twice: as to Republican Rome and as to English Law; in both cases for expanding nations ruled by a landed gentry. Today the most important territory recognizing liberty of testation, is the territory of greatest economic opportunities: the United States." ${ }^{28}$ If Weber is right, or even close, then we have strong evidence that freedom of testation is a minority view, even in the West. Practices of primogeniture or inheritance, or communal "confiscation," assume quite the opposite of the assumption that prevails in the United States today: they see some subset of the living as having rights to a person's property following his or her death.

In fact, Locke's ideas of individual property rights, from which the English and American conception of property derives, are famously responses to Filmer and Filmer's extended justification of feudal monarchic practices where individuals could no more stipulate rights of inheritance than kings could stipulate successors to the crown. ${ }^{29}$ Filmer famously derived inheritance rights, not freedom of testation, from the Abrahamic creation myth of Adam and his sons. This is to say that even among Englishmen of the recent past, free testation is far from intuitive. It would be surprising that an intuitively obvious assumption happens to be rejected by close to 100 percent of human cultures and history.

27 Murdock, "Ethnographic Atlas Codebook"; Nussbaum, "Liberty of Testation."

28 Weber, The Theory of Social and Economic Organization.

29 Filmer, Patriarcha. 
What can justify the assumption that death does not alienate me from my property rights, if not intuition? Even in Locke, who advocates freedom of testation, we cannot find a justification. Locke famously argued that nature was the common stock of mankind bestowed on humans by God, and that property rights arose from individuals mixing their labor with nature. Locke foresaw that one possible consequence of this view is that, at death, property returned to "the common stock of mankind." In response, Locke mentions freedom of testation as a natural right associated with the right of property-but never defends it. Instead, he makes an extensive case for a child's right to inheritance on the grounds that parents have an obligation to care for their children. As we have seen, though, rights to inheritance are incompatible with free testation..$^{30}$ If you are entirely free to dispose of your property at your will, then your children do not have a right of inheritance unless this is granted by your testament. Locke's stated view that there is a natural right to free testation is hard to square with his argument for children's right to inheritance. ${ }^{31}$ In defending a right to inheritance, Locke in fact opens the door for arguments that moral obligations derived from considerations wholly outside of the wishes of the dead determine the just distribution of wealth. These lines of reasoning have a subsequent history in Western philosophy: Hegel, for instance, explicitly makes the case against freedom of testation on broadly Lockean grounds, arguing that obligations to family alone determine the parameters of morally defensible distribution of wealth after death. ${ }^{32}$

Another source for the modern concept of freedom of testation comes from John Stuart Mill. In his Principles of Political Economy, Mill claimed that free testation, as opposed to inheritance, is analytic to the very concept of private property. ${ }^{33}$ But even Mill eventually recognized that this is not a tenable claim. ${ }^{34}$

30 Waldron, "Locke's Account of Inheritance and Bequest."

31 Waldron, "Locke's Account of Inheritance and Bequest."

32 Hegel, The Philosophy of Right, 216-18.

33 Mill, Principles of Political Economy, bk. 2, ch. 2, sec. 3: "Nothing is implied in property but the right of each to his (or her) own faculties, to what he can produce by them, and to whatever he can get for them in a fair market; together with his right to give this to any other person if he chooses, and the right of that other to receive and enjoy it. It follows, therefore, that although the right of bequest, or gift after death, forms part of the idea of private property, the right of inheritance, as distinguished from bequest, does not. That the property of persons who have made no disposition of it during their lifetime, should pass first to their children, and failing them, to the nearest relations, may be a proper arrangement or not, but is no consequence of the principle of private property."

34 Mill revised his view so that, by the posthumous publication of Chapters on Socialism, he takes almost nothing to be analytic to the concept of private property. "The idea of property is not some one thing, identical throughout history and incapable of alteration, but is variable like all other creations of the human mind; at any given time it is a brief expression 
A community that employed all of our current forms of property protection, including freedom of gifting, but decided that, upon death, property would be inherited by family or divided equally among all community members (or relinquished to the state), would not thereby fail to share our concept of private property. The members of this imagined community simply have a disagreement with us as to how far it extends. One can consistently believe in private property and believe that, upon death, moral considerations outside of one's own wishes determine the distribution of one's assets. That individuals have freedom of testation is a substantive assumption, not an analytic truth. ${ }^{35}$

In the end, I believe two considerations speak against the idea that death preserves property rights. The first is the consideration that with death comes the end of the subject, and therefore an end to the person with claims of rights and property. Upon death, there is no subject whose rights we are violating when we take a piece of property that was once theirs and do with it something contrary to their wishes. This is the consideration I address extensively in the final section, where I argue against the existence of posthumous harms. The other consideration is that I do not believe it is possible to consistently maintain that one's property rights survive death, but one's political rights do not. Even more importantly, it is not possible to maintain that one's property rights with respect to some kinds of property, like personal assets, survive death, but one's property rights with respect to another kind of property, like business assets, do not survive death.

I have already given reasons, in the first section, for claiming that a right of suffrage does not entail a right of posthumous suffrage, nor does freedom to make decisions with respect to a business I own entail the right to such decisions after my death. The question is whether there is a relevant difference between these political and economic freedoms, afforded to us only while we are alive, and our freedom of gifting associated with private property. I believe that there is no relevant difference.

Political rights, like property rights, can be given away conditionally. I can agree in a heavily Republican state to vote for Ralph Nader on the condition that a Nader supporter in a swing state vote for $\mathrm{Al}$ Gore. Two senators can agree to support each other's bills, which they otherwise oppose, as part of a deal. Such vote pairing, or agreements to exchange votes strategically, are quite a common

denoting the rights over things conferred by the law or custom of some given society at that time; but neither on this point nor on any other has the law and custom of a given time and place a claim to be stereotyped for ever," Fortnightly Review, $135-36$.

35 For an extensive defense of Mill's considered views on inheritance and taxation, see Cappelen and Pederson, "Just Wealth Transfer Taxation." 
occurrence in parliaments, and not at all uncommon in general elections. Similarly, business rights can be given away conditionally. I am perfectly within my rights to conduct my business strategically according to your wishes, or offload certain business decisions on other managers at a firm. Political and private business decisions are freely and conditionally given.

Rights that I hold in political and business contexts can also be similarly made into deferred gifts, as when I promise to vote for the next three Democrats on the condition that you vote for the Republican in the next election, or when I agree that I will manufacture my product in your town in the next ten years on the condition that you lower sanitation taxes. Of course there are legal and moral limits to gifting, but this is true with respect to our private property as well. I cannot give away my property to enemies of the state, for instance, or hire people to perform illegal activities in my life or my business. The state is similarly required to enforce my liberties across all of these activities during my lifetime; a state infrastructure prevents others from suppressing my vote and political activity, and civil courts enforce the contracts I make for my private business. Similarly, civil courts and law enforcement are meant to protect my private property rights.

Finally, I have stakes in the future of political institutions and my business as much as I have a stake in the future of my personal wealth. I help to erect and change political institutions with my votes and political activity. The future of a business I found and work hard to build can be even more important to me than what happens to my house. So in almost all respects relevant to their status as freely and conditionally transferable powers, my political rights, private business rights, and private property rights are the same. And yet we treat two of these as alienated at death, for good reasons, but one of them as preserved, for no discernible reason.

\subsection{An Objection and Reply}

One difference between our rights to private assets and our business assets is worth discussing. This difference threatens the argument I have been making. In some jurisdictions, you are not allowed to discriminate against certain people with respect to doing business with them as a business owner, but you are permitted to discriminate against them as a customer, i.e., spender of private wealth. For example, you cannot as a baker refuse to bake a cake for a gay wedding, but you are perfectly within your rights to refuse to purchase a cake from a business that supports gay marriage. One moral principle underlying this legal practice may be that we view business rights as more restricted than private property rights, and that this is the explanation as to why private property rights survive death but business rights do not. The view might be that private businesses inter- 
act more directly with public needs and public policies than individual private property, and that private businesses benefit more from public goods than private property, therefore giving the government justification for imposing limits on freedom in one case but not the other. Thus, the reason for prohibiting posthumous rights to business activity is because of the need to protect public goods that businesses provide but private wealth does not. On this view, we restrict posthumous business rights for public policy reasons that do not carry over to private wealth.

The reasoning here is unpersuasive to me. First, it is highly contentious whether there is a moral, rather than a practical, justification for treating businesses differently from individuals with respect to rights to discriminate. Organized consumer boycotts that wrongfully discriminate could just as well have public policy implications at least as great as those threatened by businesses that wrongfully discriminate, so the justification on the grounds of policy implications fails. The truth is, the state is actually able to enforce unjust discrimination among businesses, at least some of the time. There is no (wieldy) way to enforce claims against customers for unjust discrimination.

Second, the appeal to public goods as the justification for differential treatment is unpersuasive. Higher-net-worth individuals - those who exercise the most power due to their private property rights before and after death, benefit greatly from public, tax-funded goods, such as financial laws and federally backed insurance, the enforcement of financial regulation, the Federal Reserve, government-backed Treasury bonds, the Securities and Exchange Commission, and the highly expensive litigation system that enforces contracts at all levels of government. In the end, if one believes it is just for states to enforce what amounts to a moral prohibition on businesses that wrongly discriminate, it stands to reason that it is just for states to enforce a prohibition on customers who wrongly discriminate. Here, I am in agreement with Libertarians, who accept the contrapositive.

Turning to posthumous rights, I similarly believe there is no way to justify the denial of posthumous rights to political and business decisions on the grounds of public interest without denying such rights to private wealth on the same grounds. Here I am assuming no more of "public interest" than that it means "in the interest of the public." There is no sense of "public interest" in which bequests of private wealth are not privy to considerations of public interests, but posthumous wishes to vote or conduct business are. When large amounts of personal wealth can be squandered, hoarded, or given to charities for guinea pigs, this is as much in the public interest as when some dead industrialist wanted to keep manufacturing in a certain town. Similarly, the distribution of funding 
in the charity sector is certainly a matter of public interest. The charity sector in many ways is designed to supplement and complement failures of the state and private sector to provide for certain goods. Who has power and how much power they have in these sectors, before and after death, are as much a matter of public interest as they are in these other sectors.

The treatment of private wealth on the one hand, and business wealth and political capital on the other, is highly artificial. There is no sense in which the machine I purchase for my business is subject to one set of property rights that expire at death, and the dollar that I earn from that machine is subject to another set that is subject to freedom of testation. If the very idea of property rights requires a right to free testation, i.e., such rights are not alienated with the death of the subject, then it should require posthumous rights to business activity. If public interest considerations overrule any felt need to honor the wishes of the dead in businesses and politics, it should overrule the same need for private wealth as well.

\section{POSTHUMOUS HARM}

The philosophical justification for honoring the wishes of the dead arises from considerations of posthumous harm, something that Adam Smith recognized quite early in his writings criticizing perpetual entailed estates. ${ }^{36}$ The argument for the existence of posthumous harm rests largely on a few kinds of commonsense cases. For instance, it seems wrong to spread malicious lies about someone who is now dead. ${ }^{37}$ Second, it seems that if an author greatly wanted a book of theirs to be published, it would be wrong to throw away the manuscript now that she is dead. Finally, it seems that if you made a promise to give a dying man's locket to his grandson, it is wrong not to do so. ${ }^{38}$ These things seem wrong, even though there is no longer a subject of harm, like there is no subject who has property rights to be violated. These kinds of cases suggest that, even though the subject of harm is now dead, we still feel that some kind of harm or wrong occurs. The central philosophical problem is characterizing who has been harmed, or whose rights are violated, if the wishes of the dead are thwarted. The philosophical moves begin: perhaps not all wrongs require a subject; perhaps the sub-

Smith writes: "The difficulty is to find at what period we are to put an end to the power we have granted a dying person of disposing of his goods... The insensible progress of entails was owing to their not knowing how far the right of the dead might extend, if they had any at all" (Lectures on Jurisprudence, 165-69).

Feinberg, The Moral Limits of the Criminal Law.

Wisnewski, "What We Owe the Dead." 
ject is the premortem person; perhaps there is a sophisticated form of backward causation; perhaps the best language is not in terms of "harms" or "rights," but rather a matter of welfare and well-being, where a person's well-being during life depends on factors in the future. ${ }^{39}$ Either way, the intuitions must be preserved, even though the right philosophical theory is elusive.

To me, the commonsense cases are not particularly persuasive. Certainly, they are not persuasive enough to be foundational in a theory that grants the dead posthumous rights. First, most of the intuitive cases involve one-off, particular, and context-specific moral obligations that individual persons have to other recently dead persons. The generalizability of these kinds of cases to cases involving perpetual, institutional obligations to the dead is questionable. ${ }^{40}$ Second, consider the case of maliciously lying about the dead. Is it really wrong to spread a lie about a dead person if you stipulate that no living member of her friends or family has any stake in the dead person's reputation, and you also control for any judgment on the categorical wrongness of lying or for the objectionable states of mind or character manifest in lying about the dead? I think that if you do control for these things - ensuring that no one living cares about the lie, that the lie is not an expression of an objectionable state of mind, and that it represents a case of permissible lying - there is no wrongness left to explain. Deathbed promises are the final type of case. These promises are neither unconditional nor eternal, nor must they be satisfied at serious financial or moral cost to the living. They are, instead, a lot like living promises, which can be overridden by the circumstances of morality. ${ }^{41}$ If I promise my child some candy, but through no fault of my own the only available candy must be acquired at serious moral cost to some current candy owner, it is not morally obligatory to fulfill this promise. A promise never holds overriding moral weight. And again: Is thwarting a promise to the dead wrong in virtue of having thwarted the wishes of the dead, or because of some kind of categorical judgment on the state of mind or character of a promise breaker? Control for these variables, and I do not think it is clear that there is some intuition of harm to the dead.

Despite this skepticism, I do accept that there is something bad about thwarting someone's future-facing desires, projects, and values. This I concede to the advocates of posthumous harms. But I believe the badness does not arise from harm. Many of our most significant values depend for their realization on the ex-

See Feinberg, The Moral Limits of the Criminal Law; Pitcher, "The Misfortunes of the Dead"; Levenbook, "Harming Someone after His Death"; Wisnewski, "What We Owe the Dead"; and Portmore, "Desire Fulfillment and Posthumous Harm."

Thanks to an anonymous reviewer for this consideration.

This point is made in Wisnewski, "What We Owe the Dead." 
istence of future people, and the ways our own activities in life affect them. This is a central principle in Scheffler's Death and the Afterlife. Valuing for Scheffler is constitutively connected with conserving what is valued in a future world inhabited by human beings where such values are manifest. If the human race were to go extinct shortly after our own deaths, many of our projects would turn out not to matter anymore. ${ }^{42}$ The young adult novel I wrote, the cure for cancer I helped advance, the electoral college reform I fought very hard to push: these will all turn out not to matter if, shortly after my death, humans go extinct. It is a very short step to the idea that, even if humans continued to persist but somehow my life projects were simply erased at my death, I would similarly have engaged in insignificant or pointless activities, as my values would no longer be preserved and perpetuated. One of the most important values that gets undermined in destroying my life's work upon my death is my mark on the future, something that Scheffler convincingly argues is more significant to me, as someone with values, than even my own life. The amount of meaning, value, and significance of much of my life's work depends on its impact on the future of humankind. If there is no humankind, or if the future consists of a human race where I make no mark, or have no impact, there is a sense in which my life and life's activities have been made pointless.

Doug Portmore has called the desire for current projects and values that are future directed to be preserved after death "not-for-naught" desires. ${ }^{43}$ You would like your activities to be meaningful and impactful. You do not want them to be for naught. When those activities depend for their fulfillment on events in the future, a future under the control of future generations, then future people determine whether your work will be for naught. Because I do not want my activities to be for naught, it makes sense that I aim to set up institutions that help to guarantee a place for them. Hence, we have institutions that enforce the wishes of the dead.

Not-for-naught reasoning is pervasive even during our lives. Thomas Kelly shows that many forms of purportedly fallacious "sunk-cost" reasoning are in fact a legitimate form of not-for-naught reasoning. ${ }^{44}$ Geffen Records continued to fund the Guns N' Roses album Chinese Democracy for almost two decades,

Scheffler actually defends three different theses here: that things mattering to us depends on our confidence in the existence of a future human race, that things mattering depends on the existence of a future human race, and that things mattering to us depends on the existence of a future human race.

43 Portmore, "Desire Fulfillment and Posthumous Harm," and "Welfare and Posthumous Harm."

44 Kelly, "Sunk Costs, Rationality, and Acting for the Sake of the Past." 
putting millions upon millions of dollars into the budget of a failing album in hopes that all of the time and money that went into the production would eventually materialize into a bestseller. In the justification for continued us involvement in failing counterinsurgency campaigns in Vietnam, then Iraq and Afghanistan, there has often been an appeal to the idea that troops would have "died for nothing" if the United States abandoned the campaign at a given moment, with the foreseeable side effect that the host nation would fall into enemy hands shortly after a us withdrawal. Kelly persuasively argues that not-for-naught reasoning can very well be rational if projects turn out as intended in the long run. ${ }^{45}$ The future can just as well render projects meaningful and worthwhile as it can render them for naught.

There is a sense in which thwarting an individual's wishes after their death with respect to their conditional, charitable, or dynasty bequests undermines the perpetuation of their values into the future, values that are forward looking and depend on their realization on the fact that there is an intended impact on future generations. Milton Hershey of the Hershey Company put all of his money and his entire corporate empire under a trust to fund an orphan school of one hundred poor white male orphans, in perpetuity. ${ }^{46}$ If you decide that, upon Milton Hershey's death, his life mission of funding an orphan school is no longer enforceable by the state, and the board of his company decides instead to invest in organic milk production, you are undermining one of Hershey's forward-looking interests and values, just like you would be undermining an interest if you just burned a book manuscript a dying person wishes to be published. But does this make the thwarting, or rendering of a particular project of a dead person "for naught," a posthumous harm, or a wrong to that individual such that they have a right that we not do this?

I believe the answer is no. The mere making of a project "for naught" is not sufficient to require state enforcement of a posthumous wish. We do not have a right that individuals in the future not render our lives less significant than we would like. If our wishes and activities turn out to be in the better interests of future lives, then those wishes may continue to be honored simply because the living can recognize this and do what is best for themselves, and thus my life remains significant. But my life will be significant for the right reason, namely, because my wishes and activities are in fact good for the future world. The wishes of dead me should be honored precisely because they are the right ones to

Lest you mistake my meaning, I am certainly not saying that Chinese Democracy or the wars in Vietnam and Iraq, three of the greatest disasters of recent American history, are examples of such rational projects.

This is the primary case study in Lam, "The Wishes of the Dead." 
have for the living, and not because they are mine. Future people are not obliged to see to it that my wishes are honored so that the significance of my life may be maximized.

But I do not know whether these assertions amount to an argument. Some have a strong intuition that the rendering of people's projects insignificant is wrong. Many even consider it a backward-looking harm, affecting the premortem person. Portmore claims as much. If it is wrong, I believe it is an "impersonal wrong." There is something bad in the world with having people lead insignificant lives, but it is no harm to the person who leads this life. After all, probably lots of people have, and continue to lead, rather insignificant lives, and do not feel the worse for it. None of their values are likely to be perpetuated even in the immediate future after their death. They will make zero impact. I do not think it is harmful to these people that we do not actively make their lives more meaningful by seeking out and realizing their values.

But I am willing to concede the point for argument's sake. Perhaps it is better, all things being equal, to have in the world people who lead more significant rather than less significant lives. Perhaps it is some form of harm to the premortem person that we do things that render their lives less significant. Even with these concessions, I will now argue, the harm of being rendered less significant is not sufficient to justify the state enforcement of posthumous wishes.

Consider the following scenario: a certain author has spent his entire life finding the homeopathic cure for pneumonia, an affliction that claimed his dear mother. His book has been finished and it is his dying wish that it be published. Upon reading the book, living individuals are of the judgment that it is misguided to the point of being dangerous, and that it serves no interests of the living to have this book published. But out of respect for the dead man, they publish it anyway. Years down the line, people seeking homeopathic cures buy and use the book, and hundreds die of pneumonia as a result of not seeking standard treatments. (But as it is with all things homeopathic, people tend never to blame the book, and its influence persists.) It turns out that the result of the publication served no interest of any subsequent living individual, and in fact caused a great deal of harm.

I do not think this particular case was decided morally or prudently. Thwarting a person's valued projects can make her life less significant, to be sure-but sometimes implementing them can make her life (at least as reflected by these particular projects) positively unjust. If the former is a wrong future people can inflict on past people, then so too is the latter. The relevant principle I believe is true is that, if it is wrongful or harmful for future people to render a dead person's projects "for naught," then it is at least as wrongful or harmful for future people 
to render a dead person's projects "for wrong" or "for worse." If the future has the power to render a past project significant or insignificant, and this is a right or wrong to the individual, then the future also has the power to render such a project wrongful, and this too is a wrong to the individual.

Ultimately, it is the living who know about the effects of thwarting or implementing the wishes of the dead, since they will be the ones implementing or thwarting such wishes in a world that is quite different from the one the dead person occupied. So it will be the living who make judgments of harm and justice. If this is true, the decisions of the living to thwart or implement the wishes of the dead reduce to the decision of what policy is the best thing for the world they inhabit. If a policy is good to do, then they should do it because it is good for the living; it is fortuitous that some dead person also wanted their wealth put to this purpose. If a policy is bad to do, then they should not do it, for the fact that some dead person wanted it does not change the fact that it is bad, and doing bad in the name of a dead person is wrong or harmful to the dead person, under the hypothesis that there is posthumous harm. The fact that a wish is a wish of the dead is no moral reason to implement that wish.

As a matter of fact, there are "public policy" constraints on conditional and charitable bequests in the law just as there are "public policy" constraints on gifting. You cannot freely testate that the works of Rembrandt in your collection be set on fire, or that your fortune be donated to a drug cartel. But current public policy constraints only go so far; they do not protect the living from bequests that require them to marry or raise children within a certain religious faith, for instance, and it is still possible to word a bequest carefully enough so as to incentivize an inheritor to divorce a spouse the testator did not like. ${ }^{47}$ There is far too much control preserved for the dead even with acknowledgment that there are some public policy constraints on testation.

In the law concerning charitable giving, a topic that I have not discussed at length here but have discussed extensively in season 1 , episode 1 of the $\mathrm{Hi}-\mathrm{Phi}$ Nation podcast, there is a doctrine called cy-pres that states that, should a charitable purpose now violate the law or public policy, organizations are still legally obligated to spend money as close as possible to the wishes of the original testator consistent with public policy. ${ }^{48}$ This means, for instance, that the Hershey school can no longer discriminate against nonwhite children, since that is now illegal. But public policy does not include considerations of overall social fairness and distribution of resources. If an enormous amount of money donated to a university has as a condition that the money be spent on parapsycholog-

In Re Estate of Feinberg; Madoff, Immortality and the Law. 
ical research, but a small amount of money to the same organization has as a condition that it is spent on antibiotic-resistance research, it is of great moral significance that such money is distributed absurdly out of line with the pressing needs of today. But it is of no legal significance in terms of "public policy" provisions. So public policy is important. In fact, it is of ultimate importance, and this is certainly not reflected in the law, and we have bad philosophical ideas about posthumous rights to thank for this.

\section{CONCLUDING THOUGHTS}

In sum, I do not believe that the dead can be wronged or harmed in virtue of our rendering of their projects less significant. Thus, they do not have a right that we honor their posthumous wishes with respect to their personal wealth. However, even if we accept that they can be so harmed, those considerations lead us to conclude that they can equally be wronged or harmed if their projects are allowed to be carried out, by the living, for harmful or unjust ends, ends that the dead are unable to see and change today because they are dead. As a result, even considerations of posthumous harm do not justify the practice of honoring the wishes of the dead contrary to the needs and values of the living.

Before I conclude, I want to mention one more kind of justification I have not discussed in this paper, which concerns consequentialist justifications for freedom of testation, perpetual control, and the granting of posthumous legal rights. These views state that the existence of these things incentivizes people in desirable ways. Perhaps we need freedom of testation so that people can compete in the market for a wealthy person's bequests. Perhaps perpetual control incentivizes forward-looking, non-egoistic, and selfless concerns about the future. The idea is that if we do not allow people to become stakeholders in the future of our world, we will see a bunch of selfish egoists wantonly destroying the planet.

I have not considered these justifications because I believe that the denial of free testation, perpetual control, and posthumous rights is on quite solid footing in terms of consequentialist reasoning. The idea that we need free testation so that children will treat their parents better in an effort to win a bequest is a perversity only an economist could conjure up. To say that a world of aristocratic dynasties is better than a world in which people begin with the same set of rights and responsibilities is about as persuasive as saying that Britain during feudalism and fee tails was better than Britain today. In the charity sector, perpetual foundations simply do worse empirically than sunset foundations in producing good outcomes. ${ }^{49}$ The idea that fixed-purpose charities that last forever devised by a

49 Madoff, Immortality and the Law, ch. 3. 
person who is long dead will do more net good than charities that respond to the concerns of the best interests of the living is analytically false in any world in which charitable needs change over time.

Ultimately, we the living are to blame for sabotaging our own best interests. The dead are not around to complain if we were to stop honoring their wishes. These are our institutions, and any pain we inflict on ourselves from being worse off but for the preferences of the dead cannot honestly be held against the dead. The best we can say on behalf of our practices is that we have a self-interested desire that our interests and values not completely vanish from the world after we die, and so we erect institutions against our current interests so as to protect our future interests from future people who may undermine them. Honoring the wishes of the dead, then, is a mere side effect of our own vanity and narcissism in seeking honor when we are dead. It is time we break this cycle of absurdity, as we have in the past, and leave the best legacy we can for the living, which is the autonomy to determine the best world to make for themselves.

\author{
Vassar College \\ balam@vassar.edu
}

\title{
REFERENCES
}

Baker, John. The Oxford History of the Laws of England. Vol. 7, 1483-1558. Oxford: Oxford University Press, 2003.

Cappelen, Cornelius, and Jørgen Pedersen. "Just Wealth Transfer Taxation: Defending John Stuart Mill's Scheme." Politics, Philosophy and Economics 17, no. 3 (2018): $317-35$.

Feinberg, Joel. The Moral Limits of the Criminal Law. Vol. 1, Harm to Others. Oxford: Oxford University Press, 1987.

Filmer, Robert. Patriarcha, or the Natural Power of Kings. London: Richard Chiswell, 1680.

Grotius, Hugo. The Rights of War and Peace. Translated by A.C. Campbell. New York: M. Walter Dunne, 1901.

Halliday, Daniel. Inheritance of Wealth: Justice, Equality, and the Right to Bequeath. Oxford: Oxford University Press, 2018.

Haskins, George L. "Extending the Grasp of the Dead Hand: Reflections on the Origins of the Rule Against Perpetuities." University of Pennsylvania Law Review 126, no. 19 (1977): 19-46. 
Haslett, D.W. "Is Inheritance Justified?" Philosophy and Public Affairs 15, no. 2 (Spring 1986): 122-55

Hegel, G.W.F. The Philosophy of Right. Edited by Allan W. Wood. Cambridge: Cambridge University Press, 1991.

Jefferson, Thomas. Thomas Jefferson to Major John Cartwright, June 5, 1824. In The Writings of Thomas Jefferson, vol. 16, 42-52. Washington, DC: Thomas Jefferson Memorial Association, 1903.

Kelly, Thomas. "Sunk Costs, Rationality, and Acting for the Sake of the Past." Nous 38, no. 1 (March 2004): 60-85.

Keynes, John Maynard. The General Theory of Employment, Interest and Money. London: Macmillan, 1936.

Lam, Barry. "The Wishes of the Dead." January 31, 2017. In Hi-Phi Nation, season 1, episode 1. Podcast, 49:28. https://hiphination.org/complete-season-one -episodes/episode-one-the-wishes-of-the-dead.

Levenbook, Barbara Baum. "Harming Someone after His Death.” Ethics 94, no. 3 (April 1984): 407-19.

Luper, Steven. "Posthumous Harm." American Philosophical Quarterly 41, no. 1 (January 2004): 63-72.

Madoff, Ray D. Immortality and the Law: The Rising Power of the American Dead. New Haven: Yale University Press, 2010.

Mill, John Stuart. Chapters on Socialism. Toronto: University of Toronto Press, 1879

- Principles of Political Economy. London: John W. Parker, 1848.

Murdock, George P. “Ethnographic Atlas Codebook.” World Cultures 10, no. 1 (1998): 86-136.

Nussbaum, Arthur. "Liberty of Testation." American Bar Association Journal 23, no. 3 (March 1937): 183-86.

Otsuka, Michael. Libertarianism without Inequality. Oxford: Oxford University Press, 2003.

Paine, Thomas. Rights of Man: Being an Answer to Mr. Burke's Attack on the French Revolution. London: J. S. Jordan, 1791.

Picketty, Thomas. Capital in the Twenty-First Century. Cambridge, MA: Belknap Press, 2014.

Pitcher, George. “The Misfortunes of the Dead.” American Philosophical Quarterly 21, no. 2 (April 1984): 183-88.

Portmore, Douglas W. "Desire Fulfillment and Posthumous Harm." American Philosophical Quarterly 44, no. 1 (January 2007): 27-38.

- "Welfare and Posthumous Harm. Unpublished manuscript. http:// www.public.asu.edu/ dportmor/Welfare_and_Posthumous_Harm.pdf. 
Reich, Rob. Just Giving: Why Philanthropy Is Failing Democracy and How It Can Do Better. Princeton: Princeton University Press, 2018.

Rowe, Nicholas. "Keynesian Parables of Thrift and Hoarding." Review of Keynesian Economics 4, no. 1 (January 2016): 50-55.

Ruud, Judith K., and William N. Ruud. "Planning with the Dynasty Trust and Charity.” Gift Planner's Digest, January 4, 2000. https://www.pgdc.com/ pgdc/planning-dynasty-trust-charity.

San Antonio Express-News. "Widow Fumes at Order to Start Smoking." September 10, 1993.

Scheffler, Samuel. Death and the Afterlife. Oxford: Oxford University Press, 2013. Sitkoff, Robert H., and Steven R. Horowitz. "Unconstitutional Perpetual Trusts." Vanderbilt Law Review 67, no. 6 (2014): 1769-1822.

Sitkoff, Robert H., and Max M. Schanzenbach. "Jurisdictional Competition of Trust Funds." Yale Law Journal, 115, no. 2 (2005): 356-437.

Smith, Adam. Lectures on Jurisprudence. Edited by R. L. Meek, D. D. Raphael, and P. G. Stein. Oxford: Oxford University Press, 1978.

. The Wealth of Nations. Edited by Edwin Cannan. New York: Modern Library, 2000.

Waldron, Jeremy. "Locke's Account of Inheritance and Bequest." Journal of the History of Philosophy 19, no. 1 (January 1981): 39-51.

Weber, Max. The Theory of Social and Economic Organization. Edited by Talcott Parsons. New York: Free Press, 1947.

Wisnewski, J. Jeremy. “What We Owe the Dead.” Journal of Applied Philosophy 26, no. 1 (February 2009): 54-70. 